\title{
Sexual torture among Arabic-speaking Shi'a Muslim men and women in Iraq: Barriers to healing and finding meaning
}

\author{
Christopher Einolf, PhD*,**
}

\section{Key points of interest}

- Survivors of sexual torture experience profound psychological effects that last for years.

- Shame and concerns about honor create barriers to healing.

- In the absence of mental health treatment, survivors find meaning in their experiences.

\begin{abstract}
Introduction: Rape and sexual torture are frequent experiences among torture survivors, but relatively little is known about how victims respond to and find meaning in these experiences. Method: This study used secondary qualitative interview data from 47 male and female Shi'a Arab victims and survivors of sexual torture and rape in Saddam Hussein's Iraq to examine how sexual torture affected them, what were the barriers to healing, how they found meaning in their experiences, and how their experiences varied by gender. Results: Respondents experienced profound
\end{abstract}

*) Department of Sociology, Northern Illinois University

$\star \star)$ Director of the Center for Nonprofit and NGO Studies

Correspondence to: ceinolf@niu.edu. psychological effects that lasted for years, including: shame, feeling broken and prematurely aged, and wanting to isolate themselves from others. Most female victims who were unmarried at the time of sexual torture never got married. Many survivors found meaning in their experiences by defining their suffering as unjust, placing their experience in the context of a hopeful narrative of Iraqi history, turning to religion, and calling for vengeance upon their persecutors. Discussion: The results of this study show how survivors of sexual torture, most of whom did not receive psychological treatment, draw upon their own resources to find meaning in existential trauma.

Keywords: Barriers to healing, existential trauma, rape, sexual torture

\section{Introduction}

Rape and sexual torture are frequent experiences among torture survivors, but relatively little is known about how victims respond to and find meaning in these experiences. Existing studies tend to use quantitative measures of anxiety, depression, post-traumatic stress disorder (PTSD) and other health conditions and compare survivors with other groups. This research is valuable but limited, as it tends to treat survivors as objects of study and does not capture their full experience. Few studies 
to date have used oral history narratives to examine how survivors of sexual torture and politically motivated rape respond to torture and find meaning in their experiences (Berman, Girón, \& Marroquín, 2006; Zraly \& Nyirazinyoye, 2010). The study contributes to the understanding of sexual torture through an analysis of the testimonies of 20 men and 27 women of Shi'a Arab religion and ethnicity who were tortured during the regime of Saddam Hussein in Iraq. The study seeks the answers to the following questions:

1) What effects does sexual torture have on this sample of survivors?

2) In the absence of treatment, how does this sample of victims find meaning in their experiences?

3) Are there differences by gender?

\section{Review of the literature}

Definition and prevalence

Victims of torture are reluctant to volunteer information about sexual torture but sexual torture has been found to be common, particularly among women (Busch, Hansen, \& Hougen, 2015; Daugaard et al., 1983; Edston \& Olsson, 2007; Gorst-Unsworth \& Goldenberg, 1998; Peel, 2004). For men, the prevalence of sexual torture among samples of former political prisoners and clients at torture treatment centers ranges from $8.1 \%$ (NCTTP, 2015) to 56\% (Lunde \& Ortman, 1990). For women, it ranges from $32.1 \%$ (NCTTP, 2015) to $80 \%$ (Lunde \& Ortman, 1990).

\section{Effects}

Physical effects of rape include bleeding, bruising, and pain, but in most cases these physical effects heal relatively quickly (Clarke, 2004). Rape survivors are at a higher risk from a number of long-term health problems (Koss \& Kilpatrick, 2001).
Sexual assault and rape also have psychological effects, which may include shock, denial, fear, confusion, anxiety, shame, guilt, and distrust ( $\mathrm{Ba} \&$ Bhopal, 2017; Koss \& Kilpatrick, 2001). For many victims, psychological symptoms improve after the first few months, but some report symptoms that last for years (Yuan, Koss, \& Stone, 2006). These long-term effects include depression, generalized anxiety, attempted or completed suicide, diminished interest in or avoidance of sex, low selfesteem, and self-blame. Sexual assault victims often experience PTSD, which is characterized by emotional detachment, sleep disturbances, flashbacks, and a mental replay of the assault (Koss \& Kilpatrick, 2001). Sexual assault can separate victims from friends and family, thereby straining relationships and causing victims to withdraw from social contact. Sexual assault victims also have a lower likelihood of marriage (Centers for Disease Control, 2016). Finally, rape threatens a survivor's sense of self in the world, presenting them with "the overwhelming challenge of coping with intense psychological distress and reconstructing a world of meaning" (Koss \& Kilpatrick, 2001, p. 182).

The physical effects of torture depend on the type of torture used and vary widely (Burnett \& Peel, 2001). Psychological effects of torture include cognitive, psychological, "neuro-vegetative," and existential problems (Gerrity, Keane, \& Tuma, 2001; Hárdi \& Kroó, 2011; Johnson \& Thompson, 2008; Song, Kaplan, Tol, Subica, \& de Jong, 2015; Steel et al., 2009; Turner \& Gorst-Unsworth, 1993; Willard, Rabin, \& Lawless, 2014). Cognitive effects include confusion and disorientation, memory disturbance, and poor concentration; psychological effects include anxiety, depression, irritability, aggressiveness, and social withdrawal; and 
neuro-vegetative symptoms include lack of energy, insomnia, nightmares, and sexual dysfunction (Basoglu, 2001; Campbell, 2007; Turner \& Gorst-Unsworth, 1993). Like rape, torture "shatters" the self and challenges "the purpose of existence itself"; this "existential" effect of torture "may be one of the most important and enduring of the psychological reactions to torture, although the most difficult to conceptualize in medical terms" (Turner \& GorstUnsworth, 1993, p.7).

Some of the effects of sexual torture are similar to those of non-sexual torture, although the more "taboo and stigmatized" nature of sexual torture can make these effects more damaging (Canning, 2015, p. 12). A study of female torture survivors, of whom $76 \%$ had been raped, found that $87 \%$ of the total number had PTSD (Edston \& Olsson, 2007). According to Oosterhoff, et al. (2004, p. 71), sequelae of sexual torture include sexually transmitted diseases, unwanted pregnancies, damage to the sexual organs and rectum, PTSD, and psychosomatic disorders. Survivors also have feelings of shame, guilt, anger and anxiety, and male survivors may worry that the experience of rape has made them homosexuals.

Only a limited number of studies to date have used narrative data to examine how survivors of politically motivated rape and sexual torture have been affected by it (Berman, Girón, \& Marroquín 2006; Christian, Safari, Ramazani, Burnham, \& Glass, 2011; Sideris 2003; Zraly \& Nyirazinyoye, 2010). Two of these studies have samples of fewer than ten survivors (Berman et al., 2006; Christian et al., 2011) and two do not make the aftereffects of rape and sexual violence their main focus (Berman et al., 2006; Sideris 2003). However, these studies have generally found that sexual and gender-based violence in war and sexually torturous violence ${ }^{1}$ bring about numerous negative consequences in terms of physical and mental health problems, shame, stigma, and isolation.

In summary, there is a dearth of research on survivors' experience of sexual torture, their response to it, and its effects. Research on existential effects and how survivors find meaning in their experiences is particularly lacking. This paper takes a survivor-centered approach. Survivor stories, expressed in survivors' own words, were qualitatively analyzed to draw out the themes presented.

\section{Context for the current study}

In studying the experiences of survivors of sexual torture, this paper uses testimonies of Iraqis who were tortured under the regime of Saddam Hussein between 1973 and 2003. Saddam Hussein's regime was a notorious violator of human rights (Abdullah, 2006; Faust, 2015; Makiya, 1994; Sassoon, 2012). Coming to power through violence, Saddam believed that his government was surrounded by internal and external enemies and that only merciless control could keep his regime safe. He created multiple forces of security police that kept the country and each other under constant surveillance. These security agencies turned Iraqis against one another as the government encouraged and rewarded spies and informants.

Opposition political parties were outlawed and even minor criticisms of the regime could be punished with severe torture and death. A recent study of Iraqi refugees arriving in the United States found that $24 \%$ of a representative sample had been tortured (Willard et al., 2014).

Documented methods of physical torture included beating, hanging by the

See Canning (2015) 
limbs, long periods of forced standing, rape, sexual torture, stress positions, neardrowning, electric shock, burns from heat and chemicals, and the deprivation of food, toilet facilities, and water (Faust, 2015; Makiya, 1994; Sassoon, 2012). The forms of psychological torture reported include solitary confinement, sensory deprivation, observing the torture of others, threats to the prisoner and loved ones, and noise (Faust, 2015; Makiya, 1994; Sassoon, 2012).

While Saddam's government was extremely repressive to political opponents, Iraq was one of the more liberal Arab states regarding women's rights during his first decade in power. Iraq's oil wealth during the 1970s enabled Saddam to fund women's education and a labor shortage led to the government to encourage women to enter the labor force. Thus women gained in economic and social status during the 1970s, although these advances were reversed when the economy suffered under the Iran-Iraq war of 1980-1988, the Gulf War of 1991, and the economic sanctions of 1992-2003 (Al-Ali \& Pratt, 2009).

While the Iraqi regime encouraged women's access to education and employment, Iraqi society and family life remained highly patriarchal, although experiences varied and many women were able to make advances even within patriarchal environments (Ali, 2018). If a woman lost her virginity or engaged in apparently promiscuous behavior, the entire family's honor would be tarnished. "Honor killings" have occurred in Iraq. A contested term, honor killings are defined as "a murder carried out in order to restore honor, not just for a single person but for a collective. This presupposes the approval of a supportive audience, ready to reward murder with honor" (Wikan, 2008, p.73). Family loss of honor and the risk of honor killings can occur even if the woman lost her virginity through rape; only the fact of sexual activity, not its intent, mattered in questions of honor (Al-Ali \& Pratt, 2009; Al-Khayyat, 1990). In Iraq, where violence in the name of honor is widespread (Alinia, 2013), sexual violence against women can serve as a powerful tool to intimidate and punish opponents.

\section{Methods}

Data

The data used was collected between 2005 and 2007 by the staff of the Iraq History Project (IHP), a human rights documentation project funded by the United States Department of State and administered by the International Human Rights Law Institute at DePaul University. The Iraq History Project collected 6,982 testimonies from victims of persecution under Saddam Hussein's regime. The aim of the project was to collect and analyze "testimonies of victims, their families, witnesses, perpetrators, and others regarding human rights violations committed during Saddam Hussein's regime" (Rothenberg, 2008: p. 432). The IHP was designed as a "victimcentered initiative" that would "provide an understanding of how the Iraqi people experienced decades of systematic human rights violations" (p. 433).

The study was designed and managed by American scholars but they used a staff of Iraqi citizens to collect and transcribe the testimonies. The IHP used social networks, victims' organizations, and local nongovernmental organizations to identify and contact potential interviewees. Participation was voluntary and interviewees received no compensation. The data are identifiable and access is therefore restricted; to date, only a small number of interviews have been deidentified, translated, and made publicly 
available (International Human Rights Law Institute, 2007). Only three reports on the project have been published to date (Einolf, 2018; International Human Rights Law Institute, 2007; Rothenberg, 2008).

\section{Procedures}

Participants were matched with interviewers of the same ethnicity and gender. The interviews took place in IHP offices in different cities within Iraq; they lasted many hours and sometimes took multiple sessions to complete. Each interview followed the same process: the interviewee told their story in their own words; interviewers then followed up with questions; and the interview concluded with the interviewer slowly reading the testimony back to the respondent for clarification (Rothenberg, 2008).

The contract between the State

Department and DePaul University was cancelled in 2007 and funding was withdrawn. By this point, the IHP staff had collected approximately 3,300 Arabic and 3,700 Kurdish transcriptions of the testimonies but had not translated them and had only minimally coded them. All of the IHP staff left the project and the data were stored for four years with no access allowed to any researcher. The current author obtained the data from DePaul university staff, who had no contact with the original researchers. Fortunately, the written documentation contained fairly detailed information about the methodology of gathering the testimonies; a copy of this documentation is available from the researcher upon request.

\section{Sampling procedure}

The IHP database contained codes that labeled whether testimonies recounted rape or sexual assault. Only the Arabic cases were used for this stage of the research because the authors did not have access to Kurdish language translators. Of the 492 Arabic testimonies labeled as cases of rape and/or sexual assault, 80 were randomly selected from a printed list to translate and analyze. After mislabeled cases were removed, the remaining 47 cases (20 male and 27 female) were translated. All of these cases involved people who had been sexually tortured or raped in prison by agents of Saddam Hussein's regime.

\section{Analysis}

Narrative oriented inquiry methods were used in the analysis, coding the data from a categorical-content perspective (Hiles \& Cermak, 2008). This perspective involves taking the subtext of each interview as the unit of analysis, defining themes and categories using predetermined theory and grounded theory, assigning units of analysis to these categories, and drawing conclusions from the results. The NVivo software program was used for this analysis. An IRB approval for the analysis of the archived data was obtained to access and use the testimonies for research, under protocol number CE012916MPS.

For each question, both closed coding, derived from predetermined theory, and open coding, that used categories derived from patterns seen in the data themselves, were used. Using the UN Convention Against Torture definition as the basis, sexual and non-sexual forms of torture used on victims were coded for. With respect to the first question on the effects of torture, subjects' immediate and long-term psychological responses to torture were coded for and compared with the aftereffects of sexual torture discussed in the literature (Oosterhoff et al., 2004). Within these categories, open coding was applied to group the responses into patterns. For the second question, regarding how victims find meaning, open 
coding was used to classify responses into injustice, history, religion and vengeance.

\section{Findings and discussion}

The sample consisted of 20 men and 27 women whose torture took place during the period 1973-1999, nearly the entire span of Saddam Hussein's rule of Iraq. All were Arabs and Shi'a Muslims, a group targeted for persecution by Saddam Hussein's largely
Sunni Muslim government, and most were from southern Iraq.

The most common experiences of sexual torture were: rape (36 victims), nudity (24), beating to the sexual organs (13), and electric shock to the sexual organs, anus, or breasts (11) respectively (Table 1). Men and women were about equally likely to be targeted for these types of torture, but women ( 8 victims) were more likely than

Table 1: Number of forms of sexual torture $(n=47)$

\begin{tabular}{llll}
\hline Method & Total & $\begin{array}{c}\text { Male } \\
\mathrm{N}=20\end{array}$ & $\begin{array}{l}\text { Female } \\
\mathrm{N}=27\end{array}$ \\
\hline $\begin{array}{l}\text { Physical sexual assault } \\
\text { Groping }\end{array}$ & 9 & 1 & 8 \\
Rape & 36 & 15 & 21
\end{tabular}

Viol ence to sexual organs

Beating sexual organs

13

Electric shock to sexual organs, anus or breasts

11

Other violence to sexual organs

3

3

6

$\begin{array}{ll}7 & 6 \\ 7 & -4\end{array}$

Mental sexual assault

Nudity

Lewd comments

8

0

8

Sexual insults

Threatened rape

\section{Sexual violence to family}

Invaded family space in home

Nudity of family member

Threatened rape of family member 
Table 2: Number of respondents reporting forms of non-sexual torture $(n=47)$

\begin{tabular}{llll}
\hline Method & Total & $\begin{array}{l}\text { Male } \\
\mathrm{N}=20\end{array}$ & $\begin{array}{l}\text { Female } \\
\mathrm{N}=27\end{array}$ \\
\hline $\begin{array}{l}\text { Physical torture: } \\
\text { Beating }\end{array}$ & 38 & 16 & 22 \\
Beating feet & 6 & 4 & 2 \\
Kicking & 17 & 11 & 6 \\
Burns and scalds & 7 & 5 & 2 \\
Electric shocks & 17 & 8 & 9 \\
Hanging by arms & 11 & 10 & 1 \\
Pulled out nails & 14 & 6 & 8 \\
Other physical torture & 19 & 11 & 8
\end{tabular}

\section{Conditions of detention}

Dirty, unsanitary cell

Poor and limited food and water

Small cell

Solitary confinement

\section{Family members}

Threaten to torture family members

Threaten to kill family members

Witnessed torture of family members

Killed family member

men ( 1 victim) to be groped, and women were the only people to suffer sexual insults (11) and lewd comments (7). Torturers sometimes targeted family members for sexual abuse. When arresting a male victim at home, some security agents broke into the family area of the home where women were uncovered, an action considered to

$\begin{array}{lll}29 & 11 & 18 \\ 25 & 12 & 13 \\ 12 & 6 & 6 \\ 16 & 6 & 10\end{array}$

$\begin{array}{lll}2 & 1 & 1 \\ 2 & 0 & 2 \\ 6 & 2 & 4 \\ 2 & 0 & 2\end{array}$

bring shame upon the victim and his family (7 victims). Torturers threatened to rape family members (4) and a number followed through on this threat (3). Torturers sometimes brought a wife or sister into the detention center, stripped her (4 victims), and threatened her with rape (4). Torturers only threatened relatives of a prisoner with 
rape when the prisoner was male. Most victims of sexual torture were also victims of non-sexual torture, which is summarized in Table 2. There were no gender differences in non-sexual forms of torture except that men were more likely to be tortured by being hung by arms. Three distinct themes (with sub-themes) are presented below.

\section{Theme One: Effects of Sexual Torture}

Many victims reported their psychological reactions to torture while still in prison. All victims were tortured both sexually and non-sexually, and they did not generally distinguish between the effects of sexual and non-sexual torture. The most common psychological reactions while still in prison were: emotional outbursts ( 1 man and 6 women); deathlike emotional withdrawal ( 3 men and 4 women); self-harm (1 man and 4 women); and self-blame ( 2 men and 1 woman).

Emotional outbursts and withdrawal: The trauma of rape often caused a severe immediate emotional outburst which could go on for days. In this state, victims laughed, cried, and screamed. Some turned to self-harm, hitting their heads against the walls. "I was like a crazy person," one woman remembered, "laughing and talking to myself then crying and hitting my head against the walls, and still nothing put out the fire that was burning inside of me." Six survivors went to another extreme after the rape, withdrawing from life and emotions and feeling like they were dead. After being raped, survivors stated that "I became a semi-alive person yet dead inside," or that "I looked and felt like a dead person who is being taken to be buried... I lost the meaning of what a beautiful life is."

Self-blame: In the short term, some survivors blamed themselves for what had happened or for failing to withstand torture. For example, one man named some innocent colleagues as accomplices after the interrogators threatened to rape his wife. "I was in much regret and hated myself and didn't know how to forgive myself," he stated, "for I testified against people that I didn't know anything about." After being raped, a long-time activist in the Communist party "sat down despising myself and struggling with the pain I was going through from within. What made me become a politician? Neither me nor a million men like me can defeat Saddam's rule."

Broken and aged: Fifteen victims described themselves as psychologically broken and prematurely aged. A former activist did not return to politics, even after Saddam's overthrow, because "I felt that something inside of me has been broken and cannot be fixed." A woman stated that "I used to walk with my head up high," but now "I live broken after what has happened to me." Regarding age, there were expressions such as "I am still a young man yet I feel old as if I am in my nineties." Another stated that "I feel that my youth has been buried deep in the ground and I can no longer find it."

Shame: The next most common psychological reaction ( 1 man and 11 women) was shame, which victims defined in the terms of their culture as a loss of honor. One woman described rape as "a tragedy that struck my honor" and another equated "losing my virginity" with "losing my hope in life." The one man who mentioned feelings of shame had been left on the floor after his rape for other prisoners to see, the blood from his anus making it clear what had happened to him. Years later, when he gave his testimony, he stated that "I pray to God every day not to bump into anyone who was with me in prison who saw what happened to me." 
Many women recognized that it was unfair that they were subjected to shame given that their loss of virginity through sexual torture was not by their choice. One woman stated, "I swear I am on the path of morals and religion. Yet as the proverb says, a girl is like a white dress, if it gets stained then this stain will stay and even if it goes away there will still be traces of it. Even if I got married, who will accept my bitter truth?" Another rape victim lamented, "How hard it is for a girl to carry a burden she had nothing to do with. How hard it is for her to carry a shame that haunts her throughout her life."

Loss of marriage: Five women stated that their rape in prison made them give up any hope or desire for marriage. They assumed that their loss of virginity would make them unmarriageable, and if they lied about their loss of virginity it would be discovered on their wedding night. This is a severe consequence in a country where a woman's primary social role is marriage and children. As one woman explained: "I kept it as a secret until this moment, and I have refused to get married to any man because I did not want anybody to know about that... I keep telling my family that I am devoting my life to take care of my father... I do not want them to know the truth and to discover I am not a virgin."

In other cases, the community knew about the woman's imprisonment and guessed that she had been raped in prison. "Whoever asked about me and knew that I spent some time at the security directorate hesitated from marrying me, as if I intentionally brought this shame to myself." By contrast, only one man felt that he could not get married because of his torture and rape. He did not have any concern about lack of virginity, but stated only that "whenever I think about getting married I feel depressed."
One woman managed to hide her rape and get married, but still suffers from feelings of guilt and shame. After her release, she went to a gynecologist who resewed her hymen and she was able to get married; however, she continues to feel guilt and shame:

"I still live in major guilt thinking that I tricked my husband about who I am, even though I didn't choose that to happen and I didn't want to trick him. This is why I am not comfortable with my life although I have children now and my husband respects me and loves me, but this complex is not leaving me alone."

\section{Theme Two: Barriers to Healing and Making} Meaning of Sexual Torture

Barriers to healing: Survivors faced many barriers to psychological healing after their experience of torture and sexual torture. Only four of the forty-seven victims went to psychologists or psychiatrists. Six women never disclosed their rape to family members. One woman noted that when "they set me free I wish they hadn't, since I didn't know how I was supposed to face my mom, dad, and sister after what had happened to me. And what would be my situation if anyone in my society knew about it?" Another was so upset for so long after her release from prison that her "parents were moved to see me like this and wanted to know the truth of what has happened to me. But I kept it a secret."

Some women feared violence or death from their own families if their secret became known. Upon her arrest, one woman feared rape and "prayed to God that things will go well and to have mercy on me since my brothers will cut me to pieces and throw me to the dogs if I was accused of anything." Another rape victim kept her attack secret because "if my parents knew about what happened then they'd kill me since this is considered as a shame 
and disgrace to them." Only four women told anyone in their family about it.

Only one survivor rebelled against social mores regarding honor and insisted that coerced sex did not bring dishonor upon the victim. A mother who was forced to watch torturers rape her daughters fainted from shock and horror. "I woke up in the cell to see my daughters with their heads down, since in our tribal traditions whoever does that to a girl will be killed along with the girl, and this will be considered a dishonor. But what guilt do they hold? I saw what happened to them right before my eyes. I yelled at them, 'Don't put your heads down for you didn't bring shame to us, it was what these dogs have done." "

Finding meaning: Rape and torture attack a victim's sense of belonging to a world that is meaningful and good, so the way that survivors assign meaning to their experience is vitally important to their healing. The narratives show four ways that survivors integrated their experience into their worldview: acknowledging the injustice of their suffering, placing their own struggles in historical perspective, finding meaning in religion, and seeking vengeance.

Injustice: Self-blame is a common experience of rape survivors (Ullman 1996), and the oral history narratives recount that torturers often told their victims that they deserved torture because they were disloyal to the government. By placing their own suffering into a broader context of unjust suffering, survivors were able to resist the damaging effects of self-blame and draw meaning from their experiences. Ten survivors ( 3 men and 7 women) emphasized that the government "destroyed pure and innocent people" and the oppressors "don't discriminate between an innocent person and a guilty one." Fifteen survivors ( 7 men and 8 women) went further, stating that the government targeted the just and righteous for punishment. Saddam punished those who "spoke the truth and wanted freedom," "spoke the truth in an era full of lies and false promises," and "said 'Enough!' to Saddam's tyranny.” The most poetic articulation of this idea comes from a former teacher:

"What irony there is in how fate manipulates us, just like the soft dusty breeze moves the golden stalks that carry the beautiful seeds of wheat. In looking at them you see goodness and safety, and the farmer hopes those stalks will offer him wealth and a good harvest. But in a moment, while he remains unaware, a storm destroys everything he has planted and his dreams turn to dust. Those are the dreams of each Iraqi who was loyal to his principles and values, each lover of goodness who doesn't accept the blasphemy that destroyed so many."

History: Two men and two women placed their experiences in historical perspective, drawing upon previous examples of tyrants who were eventually overthrown. In this account, Saddam's persecutions become part of a story in which sadness and tribulation are a necessary step in a narrative that will end in the triumph of the righteous. As one man stated, "The nights of oppression have to end eventually, no matter how long the tyranny and oppression last." Similarly, another victim commented, "The righteous are not afraid of the word of truth. I am a living example of this, since despite all the torture and oppression I had, the truth was victorious."

Religion: As torture aims to undermine its victims' sense of community, spirituality and meaning, religion can help survivors heal. Common themes were thanking God ( 7 men and 7 women), resigning themselves to 
God's will (2 men and 5 women), and praying for God's help and protection (10 women). Victims also invoked God's vengeance on their oppressors ( 3 men and 8 women), which is discussed separately in the following section.

Vengeance: One of the most common themes in survivors' accounts was that of vengeance, which sixteen survivors ( 4 men and 12 women) mentioned, of whom eleven ( 3 men and 8 women) prayed for or praised God's vengeance. Saddam Hussein was on trial at the time these testimonies were taken and many praised God's vengeance upon him. One man stated that "God gives time but $\mathrm{He}$ never lets go: there is the oppressor facing his destiny behind bars just like a rat." One woman stated that the trial makes her "laugh" because "God is seeking his vengeance."

Five survivors ( 1 man and 4 women) called for vengeance without mentioning God, in phrases such as "those criminals spoiled my son's life; I wish that they get what they deserve," and "I wish I had a poisoned dagger to kill (him). Even though he suffers from fear and horror at this point I wish death for him as a punishment for what he did to me." Some took personal revenge on their persecutors after the fall of the government, and others noted pleasure that Saddam Hussein was being hung and Ba'th Party members were being punished for their crimes. Several, however, found the satisfaction of vengeance to be hollow. As one said, "Even if Saddam was hung a million times and cut into small pieces and thrown to the dogs, that still wouldn't put down the fire in my heart."

Theme Three: Differences in Experiences of and Responses to Sexual Torture

Many of the experiences and reactions described did not differ considerably by gender; however, men and women had heterogeneous experiences, which were particularly pronounced in a number of cases. Women in our sample (8 victims) were more likely than men (1 victim) to be groped, and only women reported sexual insults (11) and lewd comments (7). Torturers also only threatened to rape relatives of male prisoners. Women referred to resisting rape through physical struggle ( 1 man and 4 women) and spitting on their attacker ( 1 man and 5 women), and more women (9) than men (2) tried to resist rape and torture by begging for mercy.

The effects of torture often varied by gender. More women (11) than men (4) felt that they were broken or prematurely aged, and all but one of the twelve victims who expressed a sense of shame were women. Similarly, all but one of the seven victims who stated that they could not get married because of rape were women. In finding meaning from their experiences, more women (7) than men (3) criticized Saddam's government for targeting the innocent, and women (8) were more likely than men (3) to invoke God's vengeance on their oppressors.

\section{Limitations}

A number of limitations affect the generalizability of this study. The respondents do not form a representative sample of victims of rape and sexual torture in Iraq and they are people who voluntarily testified to the Iraq History Project. This limits the generalizability of this study as experience of sexual torture may be very different elsewhere. Kurdish testimonies are also not analyzed, which leaves out a group significantly persecuted by Saddam Hussein's regime. Perhaps most importantly, this is a sample of people who survived their persecution; many sexual torture and rape victims did not. Finally, survivors 
communicated their stories in their own words, choosing what to include and what to leave out, and may have inaccurate memories or may have given false testimony.

\section{Conclusion}

This paper explores the nature of sexual torture and its effects on victims, and identifies how survivors find meaning in their experiences. Forty-seven narrative testimonies from people who had been sexually tortured were analyzed, based on the subjects' own words. Given that most research on victims of torture studies focuses on people in treatment programs, this article offers a fresh perspective on victims who received little or no professional assistance.

This study describes how victims cope with the existential trauma of sexual torture, allowing them to convey how they understand and draw meaning from their experiences. Previous research has identified the existential trauma of rape (Koss \& Kilpatrick, 2001) and torture (Turner \& Gorst-Unsworth, 1993) as particularly severe and important, yet few studies have addressed the issue of existential trauma. This study illustrates that sexual torture survivors can find meaning in their experience, and that some Arabic-speaking Shi'a Muslim Iraqi survivors found this meaning in their ability to see their suffering as unjust, believing that righteousness prevails, and having faith in the power of God. Survivors' facility and frequency in using macro-level explanations for their very personal experiences of sexual torture conveys that they can adopt this large scale perspective.

Despite the limitations outlined, this study helps to advance existing knowledge in several ways. Methodologically, it differs from nearly all previous literature in that it uses a sample of people who did not receive asylum in a second country or assistance from a torture treatment center. This improves the similarity of the sample to the world population of torture survivors, most of whom do not escape their countries of persecution or receive professional assistance. Substantively, the article recounts how survivors describe in their own words the barriers to healing and the process of finding meaning in their experience of sexual torture.

This study presents the stories of a group of torture survivors from a single country, and the experience of sexual torture may be very different elsewhere. Future studies can further explore how survivors create meaning by referring to history, religion and justice. Another important avenue for research is to explore the desire for vengeance, whether it helps or retards healing, and how victims respond when their vengeance is realized but do not feel satisfied, as with Saddam Hussein's execution. The shame associated with both torture and rape has possibly contributed to the underreporting and neglect in research, particularly for sexual torture. Sexual torture and rape remain commonplace throughout the world. Further studies of sexual torture, both qualitative and quantitative, are sorely needed.

\section{References}

Abdullah, T.A.J. (2006). Dictatorship, Imperialism and Chaos: Iraq Since 1989. London: Zed Books.

Ali, Z. (2018). Women and Gender in Iraq: Between Nation-building and Fragmentation. Cambridge, UK: Cambridge University Press.

Alinia, M. (2013). Honor and Violence Against Women in Iraqi Kurdistan. New York: Palgrave Macmillan.

Al-Ali, N., \& Pratt, N. (2009). What Kind of Liberation? Women and the Occupation of Iraq. Berkeley: University of California Press.

Al-Khayyat, S. (1990). Honour and Shame:Women in Modern Iraq. London: Saqi Books.

Ba, I., \& Bhopal, R.S. (2017). Physical, mental and social consequences in civilians who have experienced war-related sexual violence: A systematic 
review (1981-2004). Public Health, 142, 121-135. https://doi.org/10.1016/j.puhe.2016.07.019

Basoglu, M. (2001). Psychology of Torture and its Consequences. In N.J. Smelser \& P.B. Baltes (Eds.), International Encyclopedia of the Social and Behavioral Sciences (pp. 15779-15783). Oxford, UK: Pergamon, Oxford.

Berman, H., Girón, E. R. I., \& Marroquín, A. P. (2006). A narrative study of refugee women who have experienced violence in the context of war. Canadian fournal of Nursing Research, 38(4), 32-53.

Burnett, A., \& Peel, M. (2001). Asylum seekers and refugees in Britain: The health of survivors of torture and organised violence. British Medical fournal, 322, 606-9. https://doi.org/10.1136/ bmj.322.7286.606

Busch, J., Hansen, S.H., \& Hougen, H.P. (2015). Geographical distribution of torture: An epidemiological study of torture reported by asylum applicants examined at the Department of Forensic Medicine, University of Copenhagen. Torture, 25(2), 12-21.

Campbell, T.A. (2007). Psychological assessment, diagnosis, and treatment of torture survivors: A review. Clinical Psychology Review, 27, 628-641. https://doi.org/10.1016/j.cpr.2007.02.003

Canning, V. (2015). Unsilencing sexual torture: Responses to refugees and asylum seekers in Denmark. British fournal of Criminology, 56(3), 438455. https://doi.org/10.1093/bjc/azv079

Centers for Disease Control. (2016). Sexual violence: Consequences. Downloaded on December 20, 2016, from https://www.cdc.gov/violenceprevention/sexualviolence/consequences.html.

Christian, M., Safari, O., Ramazani, P., Burnham, G., \& Glass, N. (2011). Sexual and gender based violence against men in the Democratic Republic of Congo: effects on survivors, their families and the community. Medicine, Conflict and Survival, 27(4), 227-246. https://doi.org/10.1080/1362369 9.2011 .645144

Clarke, P. (2004). Women Who Are Raped. In M. Peel (Ed.), Rape as a method of torture (pp. 4360). London: Medical Foundation for Care of Victims of Torture.

Daugaard, G., Petersen, H.D., Abildgaard, U., Marcussen, H., Wallach, M., Jess, P., Hjort, T., \& Johnsen, S.G. (1983). Sequelae to genital trauma in torture victims. Archives of Andrology: Fournal of Reproductive Systems, 10, 245-8. https://doi. org/10.1001/jama.1988.03720180051032

Edston, E., \& Olsson, C. (2007). Female victims of torture. Forensic and Legal Medicine, 14(6), 368373. https://doi.org/10.1016/j.jflm.2006.12.014
Einolf, C.J. (2018). Why do states use sexual torture against political prisoners? Evidence from Saddam Hussein's prisons. Fournal of Global Security Studies, on-line first. https://doi. org/10.1093/jogss/ogy011

Faust, A. M. (2015). Saddam Hussein's Ba'th Party: Inside an Authoritarian Regime. Austin: University of Texas Press.

Gerrity, E., Keane, T.M., \& Tuma, F., (Eds.). (2001). The mental health consequences of torture. New York: Kluwer Academic/Plenum.

Gorst-Unsworth, C., \& Goldenberg, E. (1998). Psychological sequelae of torture and organized violence suffered by refugees from Iraq. British fournal of Psychiatry, 172, 90-4. https://doi. org/10.1192/bjp.172.1.90

Hárdi, L., \& Kroó, A. (2011). The trauma of torture and the rehabilitation of torture survivors. Zeitschrift für Psychologie, 219(3), 133-142. http:// dx.doi.org/10.1027/2151-2604/a000060

Hiles, D., \& Cermak, I. (2008). Narrative psychology. In C. Willig \& W. Stainton-Rogers (Eds)., The $S A G E$ handbook of qualitative research in psychology (pp. 147-164). Thousand Oaks, CA: Sage.

International Human Rights Law Institute. (2007). Iraq History Project Testimonies. Downloaded from https://law.depaul.edu/about/centers-and-institutes/international-human-rights-law-institute/ projects/Pages/iraq.aspx.

Johnson, H., \& Thompson, A. (2008). The development and maintenance of post-traumatic stress disorder (PTSD) in civilian adult survivors of war trauma and torture: A review. Clinical Psychology Review, 28(1), 36-47. https://doi. org/10.1016/j.cpr.2007.01.017

Koss, M.P., \& Kilpatrick, D.G. (2001). Rape and sexual assault. In E. Gerrity, T.M. Keane, \& F. Tuma (Eds.), The mental health consequences of torture (pp. 177-193). New York: Kluwer Academic/Plenum.

Lunde, I., \& Ortmann, J. (1990). Prevalence and sequelae of sexual torture. The Lancet, 336(8710), 289-291. https://doi.org/10.1016/01406736(90)91814-Q

Makiya, K. (1994). Cruelty and Silence:War, Tyranny, Uprising, and the Arab World. New York: W.W. Norton.

Oosterhoff, P., Zwanikken, P., \& Ketting, E. (2004). Sexual torture of men in Croatia and other conflict situations: an open secret. Reproductive Health Matters, 12(23), 68-77. https://doi. org/10.1016/S0968-8080(04)23115-9

Peel, M., ed. (2004). Rape as a Method of Torture. London: Medical Foundation for Care of Victims of Torture. 
Rothenberg, D. (2008). The Iraq History Project: Understanding the psycho-social impact of systematic human rights violations. DePaul fournal of Health Care Law, 11, 431.

Sassoon, J. 2012. Saddam Hussein's Ba'th Party: Inside an Authoritarian Regime. Cambridge, UK: Cambridge University Press.

Sideris, T. (2003). War, gender and culture: Mozambican women refugees. Social Science $\mathcal{E}$ Medicine, 56(4), 713-724. https://doi.org/10.1016/S02779536(02)00067-9

Song, S. J., Kaplan, C., Tol, W. A., Subica, A., \& de Jong, J. (2015). Psychological distress in torture survivors: pre-and post-migration risk factors in a US sample. Social Psychiatry and Psychiatric Epidemiology, 50(4), 549-560. https://doi. org/10.1007/s00127-014-0982-1

Steel, Z., Chey, T., Silove, D., Marnane, C., Bryant, R.A., van Ommerren, M. (2009). Association of torture and other potentially traumatic events with mental health outcomes among populations exposed to mass conflict and displacement: A systematic review and meta-analysis. Fournal of the American Medical Association, 302(5), 537549. https://doi.org/10.1001/jama.2009.1132

Turner, S.W., \& Gorst-Unsworth, C. (1993). Psychological sequelae of torture. In J.P. Wilson \& B. Raphael (Eds.), International Handbook of Traumatic Stress Syndromes. Plenum Press.

Wikan, U. (2008). In Honor of Fadime: Murder and Shame. Chicago: University of Chicago Press.

Willard, C. L., Rabin, M., \& Lawless, M. (2014). The prevalence of torture and associated symptoms in United States Iraqi refugees. Fournal of Immigrant and Minority Health, 16(6), 1069-1076. https:// doi.org/10.1007/s10903-013-9817-5

Yuan, N.P., Koss, M.P., \& Stone, M. (2006). The Psychological Consequences of Sexual Trauma. Harrisburg, PA: VAWnet, a project of the National Resource Center on Domestic Violence/Pennsylvania Coalition Against Domestic Violence. Retrieved August 18, 2016, from http://www. vawnet.org.

Zraly, M., \& Nyirazinyoye, L. (2010). Don't let the suffering make you fade away: An ethnographic study of resilience among survivors of genocide-rape in southern Rwanda. Social Science E Medicine, 70(10), 1656-1664. https://doi. org/10.1016/j.socscimed.2010.01.017 